\title{
Effect of Thymine Deprivation on the Restoration of DNA Synthesis in Ultraviolet-irradiated Escherichia coli $\mathrm{B} / \mathrm{r} \mathrm{Hcr}+$
}

\author{
By JELA BROZMANOVÁ* AND MILENA SEDLIAKOVÁ \\ Department of Molecular Genetics, Cancer Research Institute, Slovak Academy of Sciences, \\ Mlynské Nivy 59, 88032 Bratislava, Czechoslovakia
}

(Received 20 November 1979; revised 25 February 1980)

The influence of a prior period of thymine and amino acid deprivation on the restoration of DNA synthesis and on the fraction of cells surviving after u.v. irradiation and subsequent incubation with chloramphenicol in Escherichia coli $\mathrm{B} / \mathrm{r} \mathrm{Hcr}^{+}$has been studied. Thymine and amino acid deprivation stimulated post-irradiation DNA synthesis and increased the fraction of surviving cells if, in the period between deprivation and u.v. irradiation, protein synthesis occurred. It is concluded that proteins induced by thymine starvation participated in the repair of u.v.-irradiated cells.

\section{INTRODUCTION}

Excision and photoreactivation of pyrimidine dimers can be suppressed in Escherichia coli strains of $u v r^{+} \mathrm{rec}^{+}$genotype if, prior to u.v. irradiation, protein and DNA syntheses are inhibited by cultivation without an essential amino acid and thymine (Sedliaková et al., 1972; Brozmanová et al., 1978). Such treatment does not result in cell death nor does it change the degree of resistance to u.v. irradiation (Sedliaková et al., 1973, 1974).

Based on evidence reported previously (Brozmanová et al., 1978) and on numerous experimental results on changes in the structural state of the DNA molecule caused by thymine deprivation (Walker, 1970; Bhattacharjee \& Das, 1973; Ghosh \& Bhattacharjee, 1975; Nakayama \& Hanawalt, 1975) we have presumed that the reduced ability of excisionproficient $E$. coli cells to excise or photoreactivate dimers is caused by changes in the DNA molecular structure rather than by decreased endonuclease or photolyase activities.

The fact that the u.v. resistance of cells does not decrease after treatment as described above, which reduces both excision and photoenzymic repair, has led us to conclude that $E$. coli $u v r^{+}$possesses an efficient repair system independent of, or only partly dependent on, the removal of pyrimidine dimers.

During the last few years it has been pointed out in several papers that treatments that injure the DNA molecule or inhibit its replication, such as u.v. irradiation, mitomycin $\mathrm{C}$, nalidixic acid and thymine deprivation, will, in $E$. coli, induce several processes which are not observed in uninjured cells. Among such responses is the enhanced synthesis of rec $A$ protein (previously protein X, Gudas \& Pardee, 1975, 1976; Little \& Hanawalt, 1977), which is not observed in lexA rec $A$ mutants and which is thought to have an important role in the repair process referred to as SOS repair (Radman, 1975; Witkin, 1976). Originally, this repair process seemed to be important only in $u v r$ mutants which are incapable of eliminating damage to the DNA molecule by excision repair. It has, however, been found that in $u v r^{+}$cells too, repair processes can be induced by a sublethal u.v. dose that will allow DNA synthesis to resume in the absence of protein synthesis, preventing the killing of cells which occurs if protein synthesis is inhibited after a lethal u.v. dose (Sedliaková \& Slezári0022-1287/80/0000-8647 \$02.00 (c) 1980 SGM 
ková, 1977). It has also been shown that, similar to a thymine and amino acid starvation pretreatment, application of an inducing u.v. dose reduces dimer excision after a subsequent u.v. irradiation (Sedliaková et al., 1978).

In the present paper we have tried to establish whether thymine and amino acid deprivation of $E$. coli $\mathrm{B} / \mathrm{r} \mathrm{Hcr}^{+}$cells will provoke an induction which, after subsequent u.v. irradiation, will restore DNA replication in the absence of de novo protein synthesis.

\section{METHODS}

Bacterial strains and cultivation conditions. Escherichia coli $\mathrm{B} / \mathrm{r} \mathrm{Hcr}^{+}$thy trp was kindly supplied by $\mathrm{Dr} \mathrm{D}$. Billen; E. coli $\mathrm{K} 12 \mathrm{AB} 2487$ recA thy thi thr leu arg pro his was kindly supplied by Dr A. K. Ganesan; E. coli K12 DM1152 lex-3 thy thi thr leu arg pro his was kindly supplied by Dr D. Mount. The synthetic glucose medium has been described elsewhere for the E. coli $\mathrm{B} / \mathrm{r} \mathrm{Hcr}^{+}$strain (Sedliaková et al., 1966) and for the E. coli $\mathrm{K} 12$ strains (Sedliaková et al., 1975). Concentrations of essential compounds were $2 \mu \mathrm{g}$ thymine $\mathrm{ml}^{-1}$ and $14 \mu \mathrm{g}$ tryptophan $\mathrm{ml}^{-1}$ for the E. coli $\mathrm{B} / \mathrm{r} \mathrm{Hcr}^{+}$strain and $2 \mu \mathrm{g}$ thymine $\mathrm{ml}^{-1}, 2 \mu \mathrm{g}$ thiamin $\mathrm{ml}^{-1}$ and $10^{-3} \mathrm{M}$ amino acids for the $E$. coli $\mathrm{K} 12$ strains. The 'heavy' medium for density labelling of DNA contained $0.1 \%{ }^{15} \mathrm{NH}_{4} \mathrm{Cl}\left(99 \%\right.$ atom purity) instead of $0.2 \%{ }^{14} \mathrm{NH}_{4} \mathrm{Cl}$ and $0.1 \%\left[{ }^{13} \mathrm{C}\right]$ glucose $(78 \cdot 2 \%$ atom purity) instead of $1 \%\left[{ }^{12} \mathrm{C}\right]$ glucose. Pre-irradiation inhibition of DNA synthesis or of DNA and protein syntheses was carried out by cultivating the bacteria in medium without thymine $\left(\mathrm{T}^{-}\right)$or without thymine and tryptophan $\left(\mathbf{T}^{-} \mathbf{A A}^{-}\right)$, respectively, prior to u.v. irradiation. Sometimes, cells cultivated in $\mathbf{T}^{-} \mathbf{A A}^{-}$were subsequently grown in the complete medium $\left(\mathrm{T}^{+} \mathrm{AA}^{+}\right)$before u.v. irradiation. Post-irradiation inhibition of protein synthesis was obtained by cultivation with $40 \mu \mathrm{g}$ chloramphenicol (CAP) $\mathrm{ml}^{-1}$ for $120 \mathrm{~min}$. Changes of the cultivation media were made by means of membrane filtration using Synpor 6 filters.

Ultraviolet irradiation. A Philips TUV $15 \mathrm{~W}$ germicidal lamp emitting predominantly light of $253.7 \mathrm{~nm}$ served as the source of u.v. radiation. The incident dose rate was $0.63 \mathrm{~J} \mathrm{~m}^{-2} \mathrm{~s}^{-1}$. The depth of the irradiated layer was 1 to $2 \mathrm{~mm}$; the suspension was stirred manually during irradiation.

Determination of DNA synthesis. During the exponential growth phase, cells were either prelabelled with [6- $\left.{ }^{3} \mathrm{H}\right]$ thymine [2.5 $\mu \mathrm{Ci}(93 \mathrm{kBq}), 2 \mu \mathrm{g} \mathrm{ml}^{-1}$; see Figs 1 and 2] or cultivated in unlabelled medium (see Fig. 5). After pretreatment and u.v. irradiation cells were, in both cases, grown in complete medium which contained [6- $\left.{ }^{3} \mathrm{H}\right]$ thymidine $\left[5 \mu \mathrm{Ci}(185 \mathrm{kBq}), 4 \mu \mathrm{g} \mathrm{ml}^{-1}\right]$ and chloramphenicol $\left(40 \mu \mathrm{g} \mathrm{ml}^{-1}\right)$. The presence of thymidine instead of thymine in the post-irradiation medium increased the fraction of cells surviving, did not enhance DNA degradation and improved the labelling of DNA after u.v. irradiation (Sedliaková et al., 1974, 1975, and unpublished results). At intervals after irradiation, $0 \cdot 1 \mathrm{ml}$ samples were transferred to Whatman no. 3 paper discs, washed with $5 \%(\mathrm{w} / \mathrm{v})$ trichloroacetic acid and then with ethanol. After drying, the radioactivity on each disc was measured in a Packard TriCarb liquid scintillation spectrometer. DNA synthesis was measured either as relative uptake of label (the increase in $\left[6-{ }^{3} \mathrm{H}\right]$ thymidine content of DNA after irradiation during post-incubation with CAP, in comparison with $\left[6-{ }^{3} \mathrm{H}\right]$ thymine content immediately after thymine starvation), or as relative incorporation (incorporation immediately after irradiation was taken as 1 ; the other values were expressed as multiples of that value).

Isopycnic CsCl centrifugation. DNA was isolated using the lysozyme (EC 3.2.1.17)/pronase procedure described by Hanawalt \& Cooper (1971). Cell lysate $(0.5 \mathrm{ml})$ was mixed with $3 \mathrm{ml} \mathrm{CsCl}$ solution to give a final density of 1.724 to $1.730 \mathrm{~g} \mathrm{~cm}^{-3}$. Samples containing $\mathrm{CsCl}$ solution were homogenized and transferred to polyallomer tubes for the $50 \mathrm{Ti}$ rotor of a Beckman L2-65B centrifuge. Centrifugation was at 35000 rev. $\mathrm{min}^{-1}$ for $40 \mathrm{~h}$ at $20^{\circ} \mathrm{C}$. After centrifugation individual fractions were collected on Whatman no. 3 paper strips. The strips were washed in $5 \%$ trichloroacetic acid and then in $96 \%(\mathrm{v} / \mathrm{v})$ ethanol and the radioactivity of the high molecular weight fractions was determined in a TriCarb liquid scintillation spectrometer.

Determination of the number of surviving cells. Samples were taken at intervals and, after appropriate dilution, the numbers of surviving cells were determined by growth on agar plates of the same composition as the corresponding liquid culture medium, solidified with $1.5 \%(w / v)$ agar.

\section{RESULTS}

We have studied the influence of thymine or thymine and amino acid deprivation on the restoration of DNA synthesis in u.v.-irradiated $E$. coli $\mathrm{B} / \mathrm{r} \mathrm{Hcr}{ }^{+}$cells incubated postirradiation with chloramphenicol. As shown in Fig. 1, exponentially growing cells, u.v, irradiated and incubated with CAP (zero time in Fig. 1) were not able to restore DNA synthesis and, due to DNA degradation, their DNA content was decreased when measured 


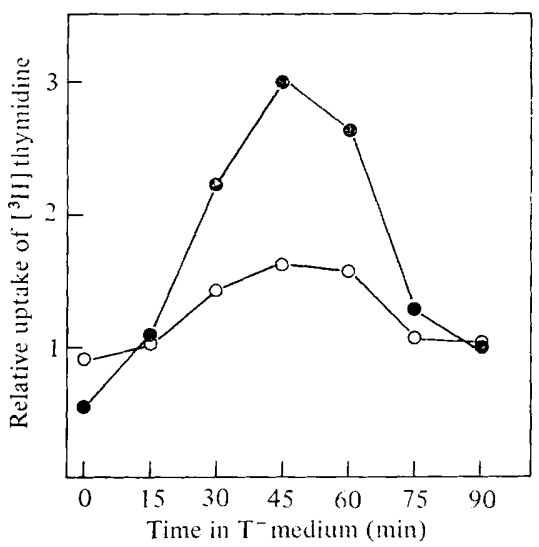

Fig. 1. Effect of prior thymine deprivation on the restoration of DNA synthesis in u.v.-irradiated E. coli $\mathrm{B} / \mathrm{r} \mathrm{Hcr}^{+}$cells incubated post-irradiation with CAP. Cells were labelled with $\left[6-{ }^{3} \mathrm{H}\right]$ thymine during the exponential phase of growth and transferred to a medium without thymine ( $\mathrm{T}^{-}$). After incubation in $\mathrm{T}^{-}$medium for the times indicated, cells were irradiated (u.v. dose $30 \mathrm{~J} \mathrm{~m}^{-2}$ ) and then incubated in the complete medium in which $\left[6-{ }^{3} \mathrm{H}\right]$ thymine was substituted by $\left[6-{ }^{3} \mathrm{H}\right]$ thymidine and CAP was added. Samples were removed after incubation for $60 \mathrm{~min}(\bigcirc)$ and $120 \mathrm{~min}(\mathrm{O})$ and their radioactivity was determined.

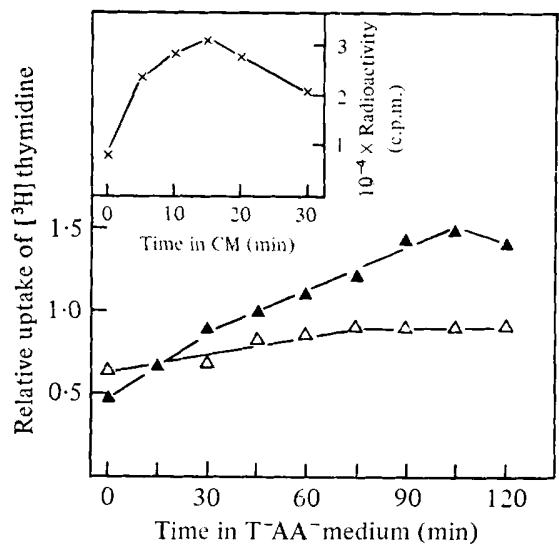

Fig. 2. Effect of prior thymine and amino acid deprivation on restoration of DNA synthesis in u.v.-irradiated $E$. coli $\mathrm{B} / \mathrm{r} \mathrm{Hcr}^{+}$cells incubated post-irradiation with CAP. Cells were labelled during the exponential phase of growth with $\left[6-{ }^{3} \mathrm{H}\right]$ thymine and transferred to a medium without thymine and tryptophan $\left(\mathrm{T}^{-} \mathbf{A A}^{-}\right)$. After incubation in $\mathrm{T}^{-} \mathrm{AA}^{-}$medium for the times indicated, one part of the cell suspension was irradiated immediately $(\triangle)$, and to the second part thymine and tryptophan were added, the cells were incubated for $15 \mathrm{~min}$ and then irradiated $(\boldsymbol{\Delta})$ (u.v. doses were $30 \mathrm{~J} \mathrm{~m}^{-2}$ ). After irradiation, cells were incubated in the complete medium in which $\left[6-{ }^{3} \mathrm{H}\right]$ thymine was substituted by $\left[6{ }^{3} \mathrm{H}\right]$ thymidine and CAP was added. At $120 \mathrm{~min}$ incubation samples were withdrawn for radioactivity determinations.

The inset shows the effect of growth in complete medium between the $\mathrm{T}^{-} \mathrm{AA}^{-}$pretreatment and u.v. irradiation, on the restoration of DNA synthesis. In the exponential phase of growth, cells were transferred to a medium without thymine and tryptophan and incubated for $90 \mathrm{~min}$. The essential compounds were then restored. After the indicated times of growth in the complete medium (CM), cells were irradiated and then incubated, as above, for $120 \mathrm{~min}$.

60 or 120 min after u.v. irradiation. Prior thymine deprivation apparently stimulated DNA synthesis in u.v.-irradiated cells incubated post-irradiation for 60 or $120 \mathrm{~min}$ with CAP, maximum DNA synthesis occurring after 45 min of $\mathrm{T}^{-}$pretreatment.

If during thymineless pretreatment protein synthesis was inhibited by simultaneous 


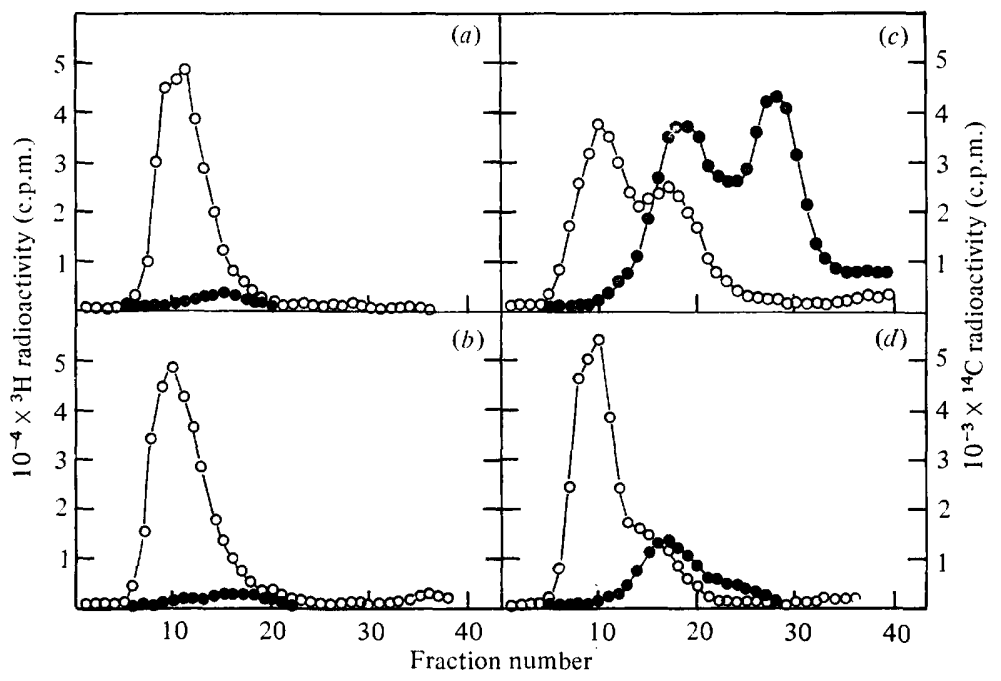

Fig. 3. $\mathrm{CsCl}$ gradient profiles of $\mathrm{DNA}$ from $\mathrm{T}^{-}$and $\mathrm{T}^{-} \mathrm{AA}^{-}$pretreated and u.v.-irradiated cells of E. coli $\mathrm{B} / \mathrm{r} \mathrm{Hcr}{ }^{+}$incubated post-irradiation with CAP. Cells were density $\left({ }^{13} \mathrm{C}^{15} \mathrm{~N}\right)$ and radioactively ([2-14 $\mathrm{C}]$ thymine, $\left.1 \mu \mathrm{Ci} \mathrm{ml}{ }^{-1}\right)$ labelled during the exponential phase of growth, transferred to the minimal 'light' medium and pretreated as follows: (a) no pretreatment; $(b)$ in $\mathbf{T}^{-} \mathbf{A A}^{-}$ medium for $90 \mathrm{~min}$; $(c)$ in $\mathbf{T}^{-}$medium for $45 \mathrm{~min}$; $(d)$ in $\mathrm{T}^{-} \mathbf{A A}^{-}$medium for 90 min and $\mathrm{T}^{+} \mathrm{AA}^{+}$ medium for $15 \mathrm{~min}$. After these treatments, cells were irradiated (u.v. dose $30 \mathrm{~J} \mathrm{~m}^{-2}$ ) and then incubated in complete medium which contained $10 \mu \mathrm{Ci}\left[6{ }^{3} \mathrm{H}\right]$ thymidine $\mathrm{ml}^{-1}$ and CAP. After 120 min samples were withdrawn. $\bigcirc,{ }^{14} \mathrm{C}$ radioactivity; $O,{ }^{3} \mathrm{H}$ radioactivity.

starvation for an essential amino acid ( $\mathrm{T}^{-} \mathrm{AA}^{-}$conditions), restoration of DNA synthesis after u.v. irradiation and 120 min incubation with CAP was not observed (Fig. 2). However, if $\mathrm{T}^{-\mathrm{AA}}$-treated cells were allowed to synthesize protein for 15 min prior to u.v. irradiation, the irradiated cells synthesized DNA during 120 min incubation with CAP. The maximum effect was reached after 90 to $105 \mathrm{~min}$ of $\mathrm{T}^{-} \mathrm{AA}^{-}$pretreatment. The influence of the period of growth in complete medium between the $\mathrm{T}^{-} \mathbf{A A}^{-}$pretreatment and u.v. irradiation on subsequent DNA synthesis is illustrated in the inset to Fig. 2.

We also followed the effect of both pretreatments on semiconservative DNA replication taking place in cells that had been u.v.-irradiated and then incubated with CAP. Exponentially growing (untreated) cells (Fig. $3 a$ ) and cells pretreated in $\mathrm{T}^{-} \mathrm{AA}^{-}$medium without subsequent incubation in complete medium (Fig. $3 b$ ) did not show any significant DNA replication. In cells pretreated in $\mathrm{T}^{-}$medium for $45 \mathrm{~min}$ (Fig. $3 c$ ) or $\mathrm{T}^{-} \mathrm{AA}^{-}$medium for $90 \mathrm{~min}$ with a subsequent $15 \mathrm{~min}$ incubation in complete medium (Fig. $3 d$ ), semiconservative DNA synthesis occurred. From these results it can be concluded that post-irradiation semiconservative DNA synthesis may be induced by thymine deprivation which is accompanied by simultaneous $\left(\mathrm{T}^{-}\right)$, or subsequent $\left(\mathrm{T}^{-} \mathrm{AA}^{-}, \mathrm{T}^{+} \mathrm{AA}^{+}\right)$, protein synthesis.

Protein synthesis between the $\mathrm{T}^{-} \mathrm{AA}^{-}$pretreatment and u.v. irradiation also increased the survival of $E$. coli $\mathrm{B} / \mathrm{r} \mathrm{Hcr}{ }^{+}$cells incubated after irradiation with CAP. The decrease in the surviving fraction of exponentially growing cells was also reduced by $\mathrm{T}^{-} \mathrm{AA}^{-}$pretreatment, more so, however, under conditions where protein synthesis occurred prior to u.v. irradiation (Fig. 4).

To determine whether the restoration of DNA synthesis after $\mathrm{T}^{-}$pretreatment of $E$. coli $\mathrm{B} / \mathrm{r} \mathrm{Hcr}^{+}$cells is a lexA-and $\mathrm{rec} A$-dependent phenomenon, we measured DNA synthesis in $\mathrm{T}^{-}$pretreated $E$. coli $\mathrm{K} 12 \mathrm{rec} A$ (Fig. $5 b$ ) and $E$. coli $\mathrm{K} 12$ lex $A$ (Fig. $5 c$ ) strains during incubation with CAP after u.v. irradiation. Under these conditions (compared with $E$. coli $\mathrm{B} / \mathrm{r}$ $\mathrm{Hcr}^{+}$; Fig. 5a) recA and lexA mutants of $E$. coli $\mathrm{K} 12$ did not show any significant DNA synthesis. 


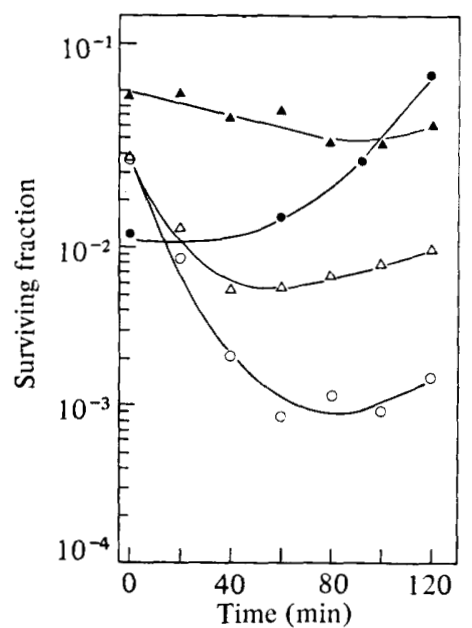

Fig. 4. Effect of $\mathrm{T}^{-} \mathbf{A A}^{-}$pretreatment on survival of $E$. coli $\mathrm{B} / \mathrm{r} \mathrm{Hcr}{ }^{+}$cells incubated post-irradiation with CAP. In the exponential phase of growth, cells were transferred to a medium without thymine and tryptophan and pretreated as follows: $O$, no pretreatment; $O$, in $\mathbf{T}^{-}$medium for $45 \mathrm{~min}$; $\triangle$, in $\mathbf{T}^{-} \mathbf{A A}^{-}$medium for $90 \mathrm{~min} ; \mathbf{A}$, in $\mathbf{T}^{-} \mathbf{A} \mathbf{A}^{-}$medium for $90 \mathrm{~min}$ and $\mathbf{T}^{+} \mathbf{A A}^{+}$medium for $15 \mathrm{~min}$. After these treatments, cells were irradiated (u.v. dose $30 \mathrm{~J} \mathrm{~m}^{-2}$ ) and then incubated in complete medium with thymidine and CAP. During incubation, at the indicated times, the number of surviving cells was determined.

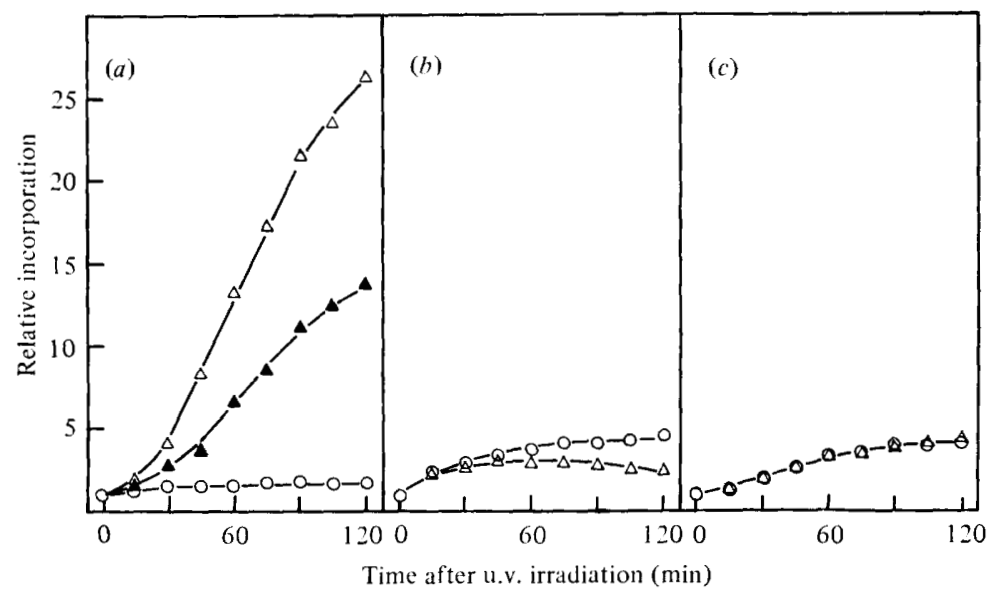

Fig. 5. Effect of thymine deprivation on restoration of DNA synthesis in u.v.-irradiated cells of $E$. coli $\mathrm{B} / \mathrm{r} \mathrm{Hcr} \mathrm{Hc}^{+}(a), E$. coli $\mathrm{K} 12 \mathrm{AB} 2487 \mathrm{rec} A(b)$ and $E$. coli $\mathrm{K} 12 \mathrm{DM} 1152$ lex-3 (c) incubated post-irradiation with CAP. All three strains were incubated in the unlabelled medium during the exponential phase of growth, then transferred to minimal medium and pretreated as follows: (a) $O$, no pretreatment; $\Delta$, in $\mathrm{T}^{-}$medium for $45 \mathrm{~min} ; \boldsymbol{\Delta}$, in $\mathrm{T}^{-} \mathrm{AA}^{-}$medium for $90 \mathrm{~min}$ and $\mathrm{T}^{+} \mathrm{AA}^{+}$medium for $15 \mathrm{~min}$. (b) $O$, no pretreatment; $\triangle$, in $\mathrm{T}^{-}$medium for $60 \mathrm{~min}$. (c) $O$, no pretreatment; $\triangle$, in $\mathrm{T}^{-}$medium for $60 \mathrm{~min}$. After these treatments, cells were irradiated [u.v. dose of $30 \mathrm{~J} \mathrm{~m}^{-2}(a)$ or $5 \mathrm{~J} \mathrm{~m}^{-2}(b, c)$ ] and then incubated in complete medium which contained $5 \mu \mathrm{Ci}$ $\left[{ }^{3} \mathrm{H}\right]$ thymidine $\mathrm{ml}^{-1}$ and CAP. At the times indicated, samples were taken and their radioactivity was determined.

\section{DISCUSSION}

Ultraviolet irradiation of wild-type $E$. coli results in transient inhibition of DNA replication at the site of the replication point. Reinitiation of DNA replication after u.v. irradiation occurs preferentially at the chromosomal origin (Billen, 1969) and can presumably start 
only when the damaged 'stalled' replication point is eliminated. This process, called reinitiation recovery, is dependent on de novo protein synthesis (Bridges, 1972). In the absence of protein synthesis after u.v. irradiation, permanent inhibition of DNA synthesis and a decrease in the fraction of surviving cells are observed (Harold \& Ziporin, 1958; Drakulic \& Errera, 1959; Doudney, 1973).

However, we found previously (Sedliaková et al., 1978) that the presence of a protein induced by the application of an initial u.v. dose enables $E$. coli $\mathrm{B} / \mathrm{r} \mathrm{Hcr}{ }^{+}$to restore DNA replication after a second u.v. dose in the absence of protein synthesis. We have now shown that thymine deprivation, when accompanied either by simultaneous or subsequent protein synthesis, has a similar effect (Figs $1,2,3 c, d$ ). The restoration of DNA replication under these conditions correlates well with the survival of u.v.-irradiated cells; under conditions which allowed synthesis of the induced protein there was practically no death of cells during post-incubation with CAP (Fig. 4). Since no DNA replication occurred after thymineless induction in the lexA and $\operatorname{rec} A$ mutants of $E$. coli $\mathrm{K} 12$ (Fig. 5) it can be assumed that this type of DNA synthesis is a lexA rec $A$-dependent SOS phenomenon.

Continuation of DNA replication in the absence of protein synthesis has been described by Kogoma \& Lark $(1970,1975)$ after various induction treatments which either damage the DNA molecule or inhibit its replication. This type of DNA synthesis, referred to as 'stable DNA replication', is a semiconservative, sequential replication. It is rec $A$-dependent and is considerably more resistant to u.v. irradiation than normal replication (Kogoma \& Connaughton, 1978).

From the above, we presume that the restoration of DNA synthesis described has characteristics similar to stable DNA replication and that enhanced synthesis of recA protein is necessary for cells to perform DNA replication in the absence of protein synthesis after u.v. irradiation. We also presume that in $\mathrm{T}^{-} \mathrm{AA}^{-}$pretreated $E$. coli $\mathrm{B} / \mathrm{r} \mathrm{Hcr}{ }^{+}$cells proteins induced by thymine starvation participate in an effective post-replication or replication repair if complete dimer excision does not occur.

We would like to thank Mrs Holá for her excellent technical assistance.

\section{REFERENCES}

Bhattacharjee, S. B. \& Das, J. (1973). Strand breaks in deoxyribonucleic acid of thyminestarved bacteria. International Journal of Radiation Biology 23, 167-174.

BILLEN, D. (1969). Replication of the bacterial chromosome, location of new initiation sites after irradiation. Journal of Bacteriology 97, 1169-1175.

BRIDGES, B. A. (1972). Evidence for a further darkrepair process in bacteria. Nature New Biology 240, 52-53.

Brozmanová, J., Mašek, F. \& Sedliaková, M. (1978). Photoreactivation of thymine dimers in thymine- and tryptophan-starved Escherichia coli $\mathrm{B} / \mathrm{r} \mathrm{Hcr}^{+}$and Hcr-. Studia biophysica 20, 221-228.

DoudNeY, C. O. (1973). Chloramphenicol effect on DNA replication on UV-damaged bacteria. Mutation Research 17, 1-12.

Drakulic, M. \& ERrera, M. (1959). Chloramphenicol-sensitive DNA synthesis in normal and irradiated bacteria. Biochimica et biophysica acta 31, 459-463.

Ghosh, N. \& Bhattacharjee, S. B. (1975). Photoreactivation of thymine starved Escherichia coli $\mathrm{B}_{\mathrm{a}-1}$. Photochemistry and Photobiology 21, 1-4.

Gudas, L. J. \& Pardee, A. B. (1975). Model for regulation of Escherichia coli DNA repair functions. Proceedings of the National Academy of Sciences of the United States of America 72, 2330-2334.

Gudas, L. J. \& PARdeE, A. B. (1976). DNA synthesis inhibition and the induction of protein $X$ in Escherichia coli. Journal of Molecular Biology 101, 459-477.

Hanawalt, P. C. \& Cooper, P. K. (1971). Determination of repair replication in vivo. Methods in Enzymology 12, 221-230.

HAROLD, F. M. \& ZiPORIN, Z. Z. (1958). Synthesis of protein and DNA in Escherichia coli irradiated with ultraviolet light. Biochimica et biophysica acta 29, 439-440.

Kogoma, T. \& Connaughton, M. J. (1978). Induced stable DNA replication as a possible SOS function. 7th Annual ICN-UCLA Symposium on Molecular and Cellular Biology, Keystone, Colorado, Abstract 159.

Kogoma, T. \& LARK, K. G. (1970). DNA replication in Escherichia coli: replication in absence of protein synthesis after replication inhibition. Journal of Molecular Biology 52, 143-164.

Kogoma, T. \& LARK, K. G. (1975). Characteriza- 
tion of the replication of Escherichia coli DNA in the absence of protein synthesis: stable DNA replication. Journal of Molecular Biology 94, 243-256.

Little, J. W. \& Hanawalt, P. C. (1977). Induction of protein X in Escherichia coli. Molecular and General Genetics 150, 237-248.

Nakayama, H. \& Hanawalt, P. (1975). Sedimentation analysis of deoxyribonucleic acid from thymine-starved Escherichia coli. Journal of Bacteriology 121, 537-547.

RADMAN, M. (1975). SOS repair hypothesis; phenomology of an inducible DNA repair which is accompanied by mutagenesis. In Molecular Mechanisms for Repair of DNA, pp. 355-367. Edited by P. Hanawalt \& R. B. Setlow. New York: Plenum Press.

Sedliaková, M. \& Slezáriková, V. (1977). Involvement of UV-induced protein in the reinitiation of DNA replication in UV-irradiated Escherichia coli. Folia microbiologica 22, 313-316.

Sedliaková, M., Slameňová, D. \& ŠTukovský, R. (1966). Changes in the radioresistance of bacteria after the inhibition of proteosynthesis in the preirradiation phase. Folia microbiologica 11, 169172.

Sedliaková, M., Mašek, F. \& Brozmanová, J. (1972). Thymine-dimer excision after the preirradiation inhibition of DNA synthesis. FEBS Letters 23, 325-326.
Sedliaková, M., Mašek, F., Brozmanová, J., MAŠKoVÁ, L., BuGÁN, J. \& SLEZÁRIKOVÁ, V. (1973). Depression of thymine dimer excision without an adequate effect on survival in Escherichia coli $\mathrm{B} / \mathrm{r} \mathrm{Hcr}{ }^{+}$cells. Neoplasma 20, 499-510.

Sedliaková, M., MAŠEK, F., Brozmanová, J., MašKová, L. \& Slezáriková, V. (1974). Depression of thymine dimer excision in various excision-proficient strains of Escherichia coli. Biochimica et biophysica acta 349, 442-446.

Sedliaková, M., Brozmanová, J., Slezáriková, V., MAŠEK, F. \& FANDLOVÁ, E. (1975). Function of the UVR marker in dark repair of DNA molecules. Neoplasma 22, 361-384.

Sedlaková, M., Slezáriková, V., Mašek, F. \& Brozmanová, J. (1978). UV-inducible repair; influence on survival, dimer excision, DNA replication and breakdown in Escherichia coli $\mathrm{B} / \mathrm{r} \mathrm{Hcr}^{+}$cells. Molecular and General Genetics 160, 81-87.

WALKER, J. R. (1970). Thymine starvation and single-strand breaks in chromosomal deoxyribonucleic acid of Escherichia coli. Journal of Bacteriology 104, 1391-1392.

WrTKIN, E. M. (1976). Ultraviolet mutagenesis and inducible DNA repair in Escherichia coli. Bacteriological Reviews 40, 869-907. 